Ewelina Kantowicz and Maksymilian Skotnicki

\title{
TRENDS IN REGIONAL GEOGRAPHY
}

When writing about Regional Geography we are facing an alriost insurmountable task. This is not only because Regional Geography has often been defined in so many ways, but due to controversies that have grown about it more abundantly than about any other geographical discipline, greatest number of divergencies in the assessment of its role, implications and actual value - from complete negation up to the highest appreciation-as well. Our abservations are not intended to deal with the applications of regional method consisting in the division of areas according to spatial diversification of selected features, a method having in fact its share in the regional physical geography as well as in the regional economic geography and other disciplines as a definite scientific approach. The point is to follow virtually a line which is based on the concept of a complex approach to the problem so as to combine natural phenomena with the activity developed by man.

Regional Geography thus conceived, forming as if a sort of bridging contact between the two grand spheres, the sphere of nature and the sphere of human activity, is of course expected to emerge from a controversial concept that there is only one geography, a concept that has always had and still now continues to have both supporters as well as fanatic opponents.

Implications of Regional Geography for the Geography taken as a whole and advancements in this field have undoubtedly been madé dependent on the views geographers had on the oneness of geography as a discipline, and historically these views must have been the outcome of dominating philosophical orientations and were changing affected by processes in the economic and social lives, the latter having been a function of the scientific progress, too.

Without going into details of the subject we may only add that the whole length of time after World War II has virtually been a period 
over which geography proceeded divided into several, generally approved, specialized branches and there could be observed a certain decline in the position of Regional Geography, accompanied also by criticism of this discipline. This found its institutional expression, too, as Regiona] Geography completely disappeared from the syllabi of the university studies in a great many British and American centres. In other parts of the world, although Regional Geography was not ruled out as a discipline, it was driven back into background or began slowly changing into a kind of the narrowly-conceived branch of geography practised within the framework of one of the regions.

The situation in Poland, though a little better than in many other Eastern European countries, did not depart far from that overall tendency observed throughout the 'world. Regional Geography has been retained as a subject, but e.g. at Warsaw University it was not so much the desire to offer synthetic analyses but to go rather into some sort of specialization in the social and economic issues of the territories outside Poland, overseas territories in particular. Attention was focused chiefly on the African and Latin-American countries. This resulted in some organizational changes; geographers began to take an active part in the organization and programmes of the Centre of African Studies, founded in 1962 and then reorganized in 1977 into the Institute of Geography of the Developing Countries. Although some of the Polish geographers noticed dangers of the ever-advancing specialization threatening with the disarray of geography (S. Leszczycki, 1979) as a science, Regional Geography which was in a pasition to prevent this was criticized itself, and is still criticized, not without reason, for having little done in the domain of research methods, for the lack of established theoretical foundations, no clearly outlined concepts, for descriptiveness and subjectivism of approach. Some others, for example J. Kostrowicki, (1967) were complaining that true regional synthetizations were getting increasingly scarce, etc.

A more or less classical monograph of the country or region continues to be further on regarded as a principal effect in treatises on Regional Geography subjects. Polish achievements in this field, although hardly comparable with the French or German contributions, have nevertheless been quite imposing. The first individual publications that deserved the name of Regional Geography Monographs, as they were fairly universal, appeared on the market long before World War I, to mention for instance the monography on Komandorskiye Islands by S. Dybowski in 1885. 
In the interwar period worth mentioning were items based to a great extent on field research being carried out by the authors themselves, such as e.g. the second Polish treatise on the Komandorskiye Islands by J. Morczewicz in 1925, or the monograph on Greenland by A. Kosiba in 1937. From among other major publications noteworthy was the series entitled "Poland's Wonders" with particular volumes devoted to the beauty of the Polish landscape and historical relics. described in connection with the principal "geographic and cultural" regions. Those volumes that were written by geographers represented in themselves regional monogiraphs on a rather good level. The greatest event of that time was the "Great World Geography" published in the thirties. Although modest in volume, it represented nevertheless a valuable contribution as regards its level, the highest one among publications that had ever appeared in print before. It stood out for its formidable intuition in feeling the relation existing between earth and man, for its "geographical sense" and synthesizing skill. In the postwar period at least 250 regional monographs have been brought to the market in the book form. Between 1945 and 1954 there were hardly any publications concerning territories outside Poland but there appeared some works on Poland's Western and Northern Territories regained as a result of war. In the years 1954-1964 several monographs covering thematically in their two-thirds the territory of Poland used to appear already each year. A marked step forward in the number of publications took place in the years 1965-1970, when more than fifty monographs came out in print on Poland and nearly thirty on other countries. From 1976 on, the number of items published each year declined amounting to no more than ten and later even less than that. From among numerous postwar monographs with almost two hundred geographers having their share in the compilation work, notwithstanding authors engaged in the preparation of collective publications, bnly a few ones have proved to be more versatile and synthetic in their character. A great many of them represent rather a kind of quasi-encyclopediae. Many either exaggerate in the amount of information furnished or suffer from its scarcity, generally unjustifiable, in sections handled. A rare event are monographs in which more than one quarter of the volume has been devoted to the theme of natural environment. An exception to this were synthetic, unfortunately seldom met, publications. The following lines of division may be drawn accordingly between all those items published:

(1) Monographs representing, in fact, a sum of information produced in an encyclopaedic form;

(2) Monographs in which authors, while keeping to the traditional 
configuration of contents, take pains to link facts discussed with each other and to show relations existing between man and natural environment, but without any synthetic summing-ups and conclusions;

(3) Comprehensive regional syntheses whose external form has been subordinated to the leading regionial problems. Publications of this kind have been really scarce and have been the outcome of long years of research and experience, as e.g. the work by J. Dylik in 1971 about the Province of Łódź.

In the classical regional monographs, including those prepared in other countries, factographic approach dominated under such circumstances. It is no wonder, therefore, that W. Bunge's opinion was getting more and more popular (W. Bunge, 1962); while considering i.a. differences between Regional Geography and Systematic Geography, he has resolved the former into sheer facts and the latter into theory, i.e. into giving explanation of causalities. In this we can reveal the old Richthofen's attitude, according to which Regional Geography was as if doomed to the remaining in the shadow of systematic sciences, gradual regressicn being the final outcome of the process.

Meanwhile, in addition to a decline observed in the interest shown for Regional Geography there was also a gradual return to it, arising either from the still-existing integrating trend or from a certain revision in the way of thinking, which has led to a "new look" at the Regional Geography. This has resulted from the new tendencies that emerged in geography under the impact of transformations the world is actually undergoing. This new glimpse or approach was a step-by-step process and it has not resulted in an all-out change of the attitude towards Regional Geography as a discipline to the effect that the idea of oneness could be assumed, but it ceased to be odd and has found its reflection in an ever-growing number of publications. Meaningful were the results of polling carried out among several scores of geographers all over the world to furnish this material for the needs of 10 Sections of the Geographic World Congress in Tokyo concerned with the Regional Geography. Most of those having been polled, among them also geographers not directly linked with the regional research as e.g. N. Ginsburg, F. Haggett, H. de Blij or Yi-fu-tuan, expressed an opinion that regional studies were important and that regional geography should be renewed in its good tradition.

Premises of such a change in the way of thinking need be sought, as already mentioned before, in the more recent trends of thought that made themselves feel both in the geography itself as well as in the processes outside science. Among the latter special attention deserved 
"energy crisis" of the seventies, "ecological crisis" as well as economic and social changes associated there with transformations in the attitudes, etc. This gave Regional Studies ecological perspective as a premise for their future development. Much interest has been taken all over the world in the man-environment problems, and all of us know what a great deal of publications dealing with the threatening scarcity of raw materials, endangerments through an increase in the rate of pollution, etc., have appeared on the market. There is no doubt whatsoever that ecological perspective is expected to lie deep in the very context of geography of which definitions, at least verbally, make reference to those problems in their majority. However, it is to be admitted that the share geographers of the world have in this throughout-geographic subject-matter, and Poland is no exception to this, proves to be more than modest. For instance, geographers took hardly any part in the man-environment programme of the Scientific Committee acting at the Presidium of the Polish Academy of Sciences, thematically linked with the UNESCO programme man and biosphere, and their share was primarily limited to the preparation of a number of voluminous collections of translated texts. In addition to this, there appeared other, quite different, tendencies. Some of the Polish theoreticians of geography do see in the man-environment subject-matter an object of studies for the Regional Geography (Z. Chojnicki, 1973) and a chance for raising up its status (R. Domański, 1977) as a science. This theme was also an object of a conference held in Warsaw in 1979 on the point of research in the Regional Geography (i.a. B. Dumanowski, 1981). In the Warsaw Centre of Regional Geography an opinion is prevailing that this branch of geography ought to take interest in establishing ties of synthesis in the relation existing between nature and man's activity, without necessarily referring to the territorial area as a medium for organizing the study? It means that with such an approach this is not imperative to bring the specific character of an area under study to the fore, but to draw conclusions on relations taking place between man and natural environment. In the broader comparative studies, including the global studies, such conclusions are designed to result, whenever necessary, in the wording of some more general regularities, being on a higher level of generalization. A suggestion may evidently be also produced that this is expected to be the task of geography as a whole, but as this fails to be put into practical use it will no doubt be necessary to fill the gap. With such an approach to the problem, analytical and synthetic studies prove to be no less important. 
The same processes, i.e. energy and ecological crises that followed in succession, started certain changes to follow in the way of human thinking and gave rise to yet another stimulus resulting in a greater interest taken in the Regional Geography, something like a kind of "the sensitivity to the site".

Fascination with the space and a whole orientation of spatial analyses in geography came into effect in the time when natural resources seemed to be almost inexhaustible and economies of the highly-developed Western countries were experiencing a period of apparent abundance. The notion of an abstract space which was well in keeping with the absence of restrictions and with the "boundlessness" could easily be seen as a direct outcome of the actual state of things. Crises gave an impact to the new outlook on reality under which the notion of an empty space began to be slowly replaced by a notion of the "realistic site". "The ideal of an unlimited development and growth has changed into an ideal of equilibrium, order, stability, quality of life, ecological humanism, organic progress, and taken account of ecological requirements, of the specific situation prevailing in society and in the economy, historical traditions of relevant countries and regions" (M. Jakubowski, 1981).

After a period of rapid progress in the quantitative methods of analysis there followed reaction. It was revealed that "revolution in the technological means" failed to be followed by "a revolution in the way of thinking". The awareness that techniques in themselves were not sufficient enough resulted in the interest directed towards a more general methodology. Young geographers ceased to look for justification of the originality of their research, as the battle for this had been fought already in the past. On the contrary, they started confronting their studies with the achievements in other fields. Certain problems were noticed to have much in common whatever the discipline which dealt with man was, Such, for instance, were problems connected with the overall philosophical perspective. Treatises confronting man's geography studies with the positivist, phenomenological, structural approach, and with Marxism were published. In the new "humanistic geography" it was the phenomenological approach that was gaining in importance and this resulted in the interest taken in the regional theme, in the context of experience-consciousness perspective with regard to site-region.

Another premise may be referred to as a process of regional transformations and new regional groupings coming into effect. On the one hand, we can observe a lasting tendency towards an ever-growing con- 
centration of economic activity in the multinational and transnational corporations. Simultaneously, as the transnational economic sectors and the transnational groupings tend to flourish all over the world, a sort of activity referred to as "an informal economy" is proliferating in the national sector to the effect that authority of "a tutelar state" is declining in favour of the local and regional, decision-making and acting, centres. Regionalisms tend to gain in significance, as there increases the part being played by the local seif-governments. This steps up interest in the theoretical and pragmatic programmes of the regional studies. Links existing between regional studies and the planning or practice often lead to the process of identifying regional geography with the applied geography. On the other hand, in the sphere which has weaker ties with the practical side of life, this tendency creates demand for solving complex geographical problems.

Thus, although the above-mentioned polling had little practical effect on the Congress in Tokyo, and most opinions quoted remained nothing else but only sheer declarations, an ever-growing number of geographers is however recognizing oneness of their discipline as a raison d'être; also the number of those perceiving the dangers of narrow specializations is increasing. Even in the Soviet Union, where the principle of isolating physical geography from economic geography was normally in operation, oneness of geography as a discipline has officially been recognized and negation of this is regarded as resulting from the methodologically erroneous premises. Characteristic are also attitudes of those who fail to be convinced of such a oneness. R. Brunet (1982) in his report on the state of French Geography thinks that declarations of the "sacrosanct" but "non existing" oneness of geography ought to be regarded as "identification fetishes" for geographers who usually deal also with such problems as urban trade or planation surfaces. But among the "ways of hope" for the progress of our discipline, enumerated by Brunet, integration concepts are found in seven of them.

However, let us return to the above-presented premises for the restoration of Regional Geography and let us review, in their context, attitudes of the present day:

(1) Regional Geography is a discipline by which a sum of knowledge is furnished about various parts of the world;

(2) Regional Geography investigates sites (territories or regions) from the ecological perspective, from the point of view of "consciousness-experience" context in a historical approach because of its internal diversification, from the viewpoint of processes thanks to which it has been organized and is functioning; 
(3) Regional Geography results in the isolation of regions;

(4) Regional Geography is an applied geography. Supporters of this concept emphasize the need for attitudes adapted to the requirements of regional planning and various expertises;

(5) Regional Geography ought to lead to a synthesis in the relation between natural environment and man's activity without necessarily considering the area as a medium towards organizing the studies.

Accordingly, almost all the historical attitudes towards Regional Geography and its problems can be found in the nineteen eighties. They are not new: why then have they been felt as such by a great many geographers? Maybe because in the new context they are found more advantageous for Regional Geography than this was usual over the past two decades when specializations were deepening and quantitative methods were becoming more and more popular in use. One may think that the present situation may appear more fitting the concept of Regional Geography. Its qualities arising from the idea of oneness seem to match better the overall intellectual atmosphere, to comply as if with the approach to reality around us and to scientific research. The way in which a great many contemporary geographers are thinking about contacts with other disciplines seems to be nearer the Ritter's or Humboldt's idea of oneness than the attitude of geographers of the sixties, well-specialized in some narrow isolated sections.

It is possible that the new approaches to the Regional Geography, as presented above, will turn out in the future to be of really little value and short-lasting. However, a look at the progress in Regional Geography from the viewpoint of relation existing between advancement of science and processes taking place in the world will provide room for some optimism as to its further perspectives. In the Geography itself a reaction starts to be felt to the uncontrollable process of dividing this discipline into the increasingly narrow and deepening specializations which destroy oneness and annihilate any common ground for research, endangering existence of this discipline and sometimes imposing also a rigid corset of the built-up organizational structures upon so-very-promising studies.

\section{REFERENCES}

Brunet, R., Rapport sur la géographie française. L'espace géographique, 1982, Vo!. XI, No. 3, pp. 196-214.

Bunge, W., Theoretical Geography, The Royal University of Lund, Lund 1962, Chojnicki, Z., „Założenia i perspektywy rozwoju geografii ekonomicznej” (Assump- 
tions and procpects for development of economic geography), Przeglad Geograficzny, 1973, Vol. ILV, No. 1, pp. 4-27.

Domański, R., Geografia ekonomiczna (Economic Geography), PWN, Warszawa 1977. Dumanowski, B., „Geografia regionalna jako dyscyplina badawcza" (Regional geography as a scientific discipline) Przeglad Geograficzny, 1981, Vol. LIII, No. 1, pp. 87-94.

Dybowski, B., Wyspy Komandorskie (Komandorskiye Ostrova), Lwów 1885.

Dylik J., Województwo ze stolica bez antenatów, (The Voivodship with a Capital without Ancestors), PWN, Eádź 1971.

Jakubowski, M., „On the notions: developed contries, developing contries, the third world and the need of new geographical divisions", Prace Geograficzne, 1981, No. 141, pp. 33-39.

Kosiba, A., Grenlandia (Greenland), Lwów-Warszawa 1987.

Kostrowicki, J., „Zagadnienia specjalizacji i integracji w geografii ekonomicznej” (The problem of specialization and integration in economic geography), Przeglad Geograficzny, 1967, Vol. XXXIX, N.o. 1, pp. 13-3i2.

Leszczycki, S., „Rozwój geografii polskiej w sześćdziesięcioleciu 1918-1978” (Development of Polish geography between 1918 and 1978), Przeglqd Geograficz$n y, 1979$, V.ol. LI, No. 3, pp. 411-455.

Morczewicz, J., Komandory (Komandiorskiy Ostrova), Warszawa 1925. 
